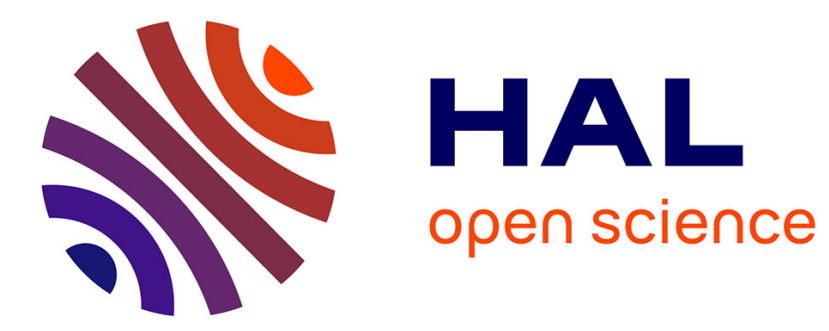

\title{
Role of Phosphate in the Remediation and Reuse of Heavy Metal Polluted Wastes and Sites
}

\author{
Ange Nzihou, Patrick Sharrock
}

\section{To cite this version:}

Ange Nzihou, Patrick Sharrock. Role of Phosphate in the Remediation and Reuse of Heavy Metal Polluted Wastes and Sites. Waste and Biomass Valorization, 2010, 1 (1), pp.163-174. 10.1007/s12649009-9006-x . hal-01634023

\section{HAL Id: hal-01634023 \\ https://hal.science/hal-01634023}

Submitted on 7 Mar 2019

HAL is a multi-disciplinary open access archive for the deposit and dissemination of scientific research documents, whether they are published or not. The documents may come from teaching and research institutions in France or abroad, or from public or private research centers.
L'archive ouverte pluridisciplinaire HAL, est destinée au dépôt et à la diffusion de documents scientifiques de niveau recherche, publiés ou non, émanant des établissements d'enseignement et de recherche français ou étrangers, des laboratoires publics ou privés. 


\title{
Role of Phosphate in the Remediation and Reuse of Heavy Metal Polluted Wastes and Sites
}

\author{
Ange Nzihou $\cdot$ Patrick Sharrock
}

\begin{abstract}
Heavy metal pollution is a major environmental concern because of the toxicity to humans and plants. This toxicity is lethal even in trace quantities and metals have a great tendency to bioaccumulate. The efficiency of phosphate and apatites $\mathrm{M}_{10}\left(\mathrm{PO}_{4}\right)_{6}(\mathrm{OH})_{2}, \mathrm{M}$ : Metal, in particular, in removing and immobilizing heavy metals from wastewater, groundwater (as permeable reactive barriers for in situ site remediation), fly ash, dredged sludges and contaminated soil has led to various studies to understand and explain the mechanisms involved. This paper will address the use of apatite as sorbent and stabilizing agents for the removal of heavy metals from various media. Efficient physico-chemical immobilization of heavy metals brings new perspectives for reuse of polluted waste water, soils and land treated by selected phosphates.
\end{abstract}

Keywords Phosphates - Apatites - Heavy metals · Remediation $\cdot$ Waste $\cdot$ Sites

\section{Introduction}

The presence of heavy metals in our environment is increasingly due to industrial pollution of the atmosphere,

\footnotetext{
A. Nzihou · P. Sharrock

Université de Toulouse, 118 route de Narbonne, 31077 Toulouse Cedex, France
}

\section{A. Nzihou}

Ecole des Mines d'Albi-Carmaux, RAPSODEE,

Campus Jarlard, 81013 Albi CT Cedex 09, France

P. Sharrock $(\bowtie)$

IUT Toulouse 3 Paul Sabatier, LERISM, Ave. Pompidou, 81104 Castres, France

e-mail: patrick.sharrock@iut-tlse3.fr waterways, soils and sediments. Contrary to organic molecules which can be metabolized or destroyed, metals can only be transformed from labile toxic forms to more inert insoluble and less bio-available forms to minimize their harmful effects on living organisms.

Soluble phosphate was widely investigated as a means of chemical treatment for the conversion of heavy metals into insoluble compounds. Phosphoric acid, ammonium, sodium and potassium phosphates will react with multivalent cations to form insoluble orthophosphates. Several hydrogen or dihydrogen phosphates have been investigated also with the aim of scavenging soluble heavy metals. The end products of the reactions of soluble phosphates with metal ions are insoluble metal phosphate salts akin to naturally occurring minerals which are stable in geological environments.

Hydrargyrite, $\mathrm{Pb}_{5}\left(\mathrm{PO}_{4}\right)_{3} \mathrm{Cl}$, is a typical example of a lead phosphate with very low solubility in a wide $\mathrm{pH}$ range [1]. Another frequently encountered example is the apatite family, with hydroxylapatite, $\mathrm{Ca}_{5}\left(\mathrm{PO}_{4}\right)_{3}(\mathrm{OH})$, (HA), the lead member of a large class of substituted compounds of similar structures. Solid solutions may be formed with a large range of concentrations of divalent or trivalent metals replacing calcium, and with fluorine or chlorine substituting for hydroxyl ions and carbonate, vanadate or arsenate found in lieu of phosphate.

Fish bones and the skeleton of mammals are composed of calcium phosphate closely resembling HA. Bones, bone char and synthetic HA have been examined for their capacity to retain heavy metals by absorption from aqueous solutions. HA can effectively be used for the treatment of heavy metal polluted waste materials.

In this review we will examine recent developments in the treatment with calcium phosphate of solid and liquid streams contaminated with heavy metals. We will begin with a review of the physicochemical properties of HA and 
its capacity to sorb heavy metal ions. Sorption is the loss of a chemical species from an aqueous solution to a continuous solid phase. Adsorption to form a monolayer is the two-dimensional accumulation of matter at the mineralwater interface at specific sites. Multiple layers may also form at an interface by adsorption processes. Precipitation is the three-dimensional growth of a solid phase.

The use of natural or synthetic HA will be presented with comments on the mechanisms proposed for heavy metal adsorption. Treatment of heavy metal polluted water will be considered as well as the formation of barriers for remediation of contaminated soils or sediments.

\section{The Apatite Family}

Hydroxylapatite, $\mathrm{Ca}_{5}\left(\mathrm{PO}_{4}\right)_{3}(\mathrm{OH})$, (HA) has a low solubility product [2] of $\mathrm{K}_{\mathrm{sp}}=5 \times 10^{-119}$. Carbonated HA constitutes the inorganic phase present in the bones of mammals and is very stable under normal environmental conditions. It does however dissolve in acidic solution to generate calcium cations and hydrogenophosphate anions, but remains stable under basic $\mathrm{pH}$ conditions. In pure water (with no added phosphate or calcium) the point of zero charge is precisely at the neutral $\mathrm{pH}$ value of $\mathrm{pH} 7$ and defines the point where negative and positive charges are found in equal amounts on the surface of solid particles. The surface of HA particles are hydrated when present in aqueous media [3] and the surface phosphate groups are protonated near $\mathrm{pH}$ 7. Calcium and phosphate sites are not present in equal amounts: the theoretical values are 3.1 and 5.1 atom $\mathrm{nm}^{-2}$ for calcium and phosphate respectively. Figure 1 shows the equilibria involved. Under basic $\mathrm{pH}$ conditions the outer surface of HA solids will be negatively charged whereas under acidic conditions it will be positively charged.

Substitutions are ubiquitous in apatite chemistry and a wide variety of ions can be incorporated into the apatite structure. Fluorine can replace hydroxide ion, carbonate can be found in lieu of phosphate, and divalent metal ions can substitute for calcium ions in large proportions. The easy formation of mixed metal phosphates can explain the capacity of HA to remove heavy metals from aqueous solutions and retain them in the solid phase. Figure 2 illustrates the crystal structure of HA pointing out all the

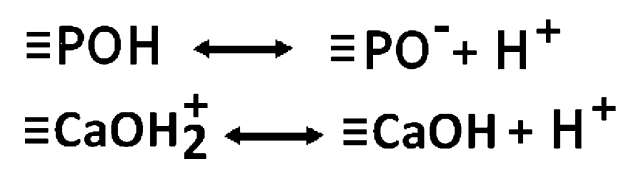

Fig. 1 Illustration of the charged groups present on HA surfaces

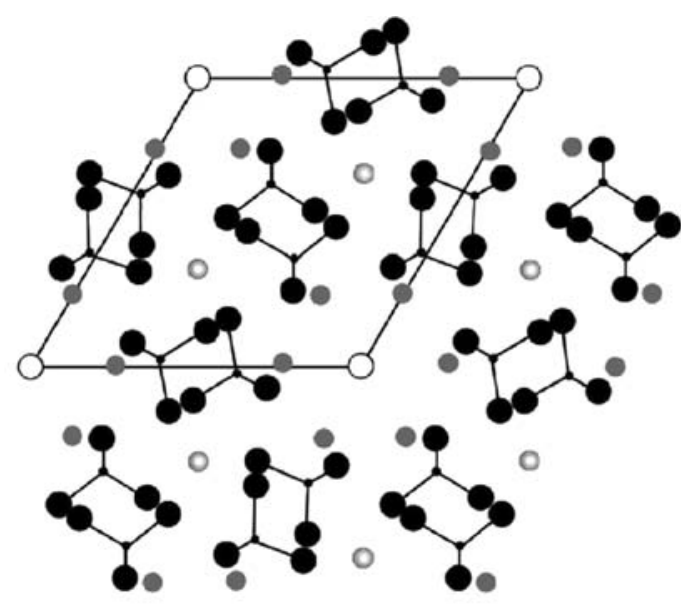

$\cdot \mathrm{P} \bullet \mathrm{O}(\mathrm{PO} 4) \circ \mathrm{O}(\mathrm{OH}) \circ \mathrm{Ca}(1) \bullet \mathrm{Ca}(2)$

Fig. 2 Hydroxylapatite crystal structure seen down the hexagonal axis. The central hydroxyl group lies in a tunnel surrounded by $\mathrm{Ca}(1)$ calcium atoms bound to phosphate groups

exchangeable groups, including the two crystallographically different calcium atoms.

\section{Water Purification with Apatites}

The first reports on the use of HA for metal ion capture from aqueous solutions were generated by Suzuki and collaborators in 1981 [4]. They discovered that HA collects heavy metal ions such as lead, copper and cadmium ions by exchange with calcium in its main structure. The group published data on single heavy metal sorption on HA as well as multi-metal sorption experiments showing that lead ions are preferentially picked up by HA, and can even replace other metals previously sorbed $[5,6]$. Binary and ternary equilibria were discussed, selectivity coefficients and values of mass transfer coefficients were determined. The rate of mass transfer was obtained for various ions and discussed in terms of film diffusion and an exchange process of ions at specific sites of the apatite structure.

The first basic conclusion was that the phenomenon taking place was a simple ion exchange between a part of the calcium ions in the apatite structure and the heavy metal ions in the aqueous phase, provided no exchange of calcium took place with protons. Indeed, the authors recognized that HA "decomposes" in acidic solutions. However, even under slightly acidic conditions ( $\mathrm{pH}$ near 5), examination of breakthrough curves suggested that a very small amount of HA actually dissolved in the aqueous phase at the same time as ion exchange. When the $\mathrm{pH}$ was smaller than 3, HA crystals were observed to dissolve 
gradually by neutralization of the protons. Experiments conducted in the region of $\mathrm{pH} 5-6$ showed rectangular isotherms, or irreversible isotherms, for all the systems investigated. Under these conditions it was found that the exchange reaction did not have a serious effect on the apatite structure. In any case, the HA structure was maintained and the divalent heavy metal ions were held in the structure. The rate of metal exchange was found to be particularly rapid for lead ions and it was concluded that the fast reaction seems to take place at the surface of the apatite particles.

The ranking of the ions according to the amount exchanged revealed that transition metals were more strongly sorbed than alkaline earth ions. To explain the differences observed between the various metal ions, a dehydration mechanism was proposed to be a rate determining step. Because dissolved heavy metal ions are associated with bound water molecules acting as ligands, the water to metal coordination bonds first have to be broken before exchange can take place with calcium ions at the surface of the HA. Lead ions have a lower enthalpy of hydration than calcium ions, and cadmium ions have a higher enthalpy of hydration, providing an explanation why lead ions are collected in a larger amount than other ions which form strong aqua complexes. Electronegativity and ionic radius mismatch were also invoked to compare the various ions and their capacity to exchange for calcium ions. It was also found that lead ions exchange very quickly with calcium ions, but that a slower process continues to remove lead from solution with time. It was recognized that the kinetics of metal sorption showed the coexistence of two processes. The fast initial mass transfer was related to the surface ion exchange reaction while the slower process was assumed to correspond to mass transfer resistance, described as governed by solid diffusion rather than by pore diffusion or surface diffusion. Thus the predominant resistance to mass transfer for heavy metal ions lied in intra-particle diffusion.

\section{Mechanisms of Heavy Metals Removal from Aqueous Phase}

In general, ion conducting channels and exchangeable ions are located in flexible frameworks that can adapt to its filling and chemistry by changing their lattice constants. HA has calcium ions located on external crystal faces and also along the tunnels that penetrate its structure. Members of the apatite family are thus ideally suited for extensive ion exchange reactions. The HA structure is tolerant to many substitutions and even complete replacement of calcium ions with other ions as well as the formation of solid solutions [7]. However, intra-particle diffusion is difficult and slow at room temperature. Mixtures of apatites form a one phase solid solution when heated near sintering temperatures [8]. The formation of secondary phases during exposure of HA to metal ions results in the formation of precipitates with low solubility on the HA surfaces effectively clogging the possible tunnel pathways for metal uptake inside the polycrystalline particles. Diffusion is then overwhelmed by accumulation of amorphous products causing mass transfer resistance. The common observation of the dual kinetics of heavy metal ion sorption on HA with the rapid first step limited in exchange capacity and related to specific surface area led authors to propose a dissolution-precipitation mechanism for the second slower step. Indeed, under acidic $\mathrm{pH}$ conditions when HA will dissolve more readily, HA shows increased capacity for heavy metal ion removal [9]. This has led to some confusion concerning the actual mechanism responsible for the global exchange capacities and exchange rates [10].

The two mechanisms most often cited for heavy metal capture by HA are the ion-exchange process and the dissolution-precipitation process [11]. In the first case, the metal attaches to the HA surface or diffuses inside and provokes calcium release by pushing out the more soluble endogenous calcium ions. The smaller solubility of the heavy metal phosphate pushes the exchange reaction towards release of calcium ions. In the second case, calcium is dissolved first, together with accompanying phosphate ions, and the heavy metal ions precipitate by homogeneous (in solution) or heterogeneous (on the remaining solid HA) nucleation [12, 13]. Both mechanisms can account for the fact that the sorption reaction slows down considerably after the initial HA surfaces are covered by less soluble phosphates. Following ion exchange, the new less soluble metal phosphate forms a coating which prevents subsequent dissolution of the underlying calcium ions and blocks the exchange reaction. This is similar to the effect of heavy metal phosphate coating of HA particles caused by heterogeneous precipitation [14]. In any case the final result is the removal of a certain quantity of heavy metal ions depending on the HA crystallinity [15], density, specific surface area, composition and other factors such as $\mathrm{pH}$, metal concentrations, rate of addition, temperature and presence of ligands [16-20]. The literature on this subject has been reviewed [21].

Another important observation reported on examination of lead ions sorption on HA is the $\mathrm{pH}$ drop correlated with the initial fast metal uptake. This phenomenon can be explained by the formation of a metal-phosphate bond replacing the protonated surface phosphate groups. This also explains the lag in calcium release during the initial periods of lead fixation in column flow-through experiments. Recent evidence points to surface complexes formed by substituting surface protons or calcium ions by 
incoming metal ions [22, 23]. In the case of cupric ions, the large differences in radii between exchanging ionic species inhibits migration into the inner part of the HA structure. EXAFS study concludes that the fixation of copper in the calcium sites in the interior of the HA crystal is unlikely. The same applies to uranium [24-26].

\section{The Various HA Forms}

Synthetic HA is not the only form of calcium phosphate used in metal removal investigations [27, 28]. Fish bones resulting from fishing waste have been studied as well as bone char and meat and bone meal calcination residues [29, 30]. Fishbones, a natural apatite, was found to be comparable to hydroxyapatite on a Ca content basis for removal of various aqueous heavy metal ions [31-34]. It compares favorably to apatite ores because of its purity and lower substitution of undesirable metals. When the fishbones were dried, crushed and fired in air at $900^{\circ} \mathrm{C}$ the immobilization property of fishbone apatite was improved. Thomson et al. [35] compared several natural and synthetic apatites in batch studies and column tests and reported the synthetic products had higher capacities than the natural products. On the other hand, Dybowska et al. [36] reported that meat and bone meal sterilized according to EU standards (containing 25\% HA and $75 \%$ organic matrix) and then incinerated at 725 or $850^{\circ} \mathrm{C}$ performed as well as synthetic apatite and better than natural rock phosphate. The reactivity of apatites for all tested metals $(\mathrm{Pb}, \mathrm{Cd}, \mathrm{Cu}$ and $\mathrm{Zn})$ followed the general order: synthetic $>$ biological $>$ mineral. Cheung et al. studied the sorption of metal ions from aqueous solution using bone char [30] composed mostly of HA but containing 9-11 wt\% carbon contributing $50 \%$ of the overall $100 \mathrm{~m}^{2} \mathrm{~g}^{-1}$ specific surface area. They found that the sorption mechanisms can be attributed to at least three pathways:

1. Ion exchange of divalent metal ions from hydroxyapatite.

2. Sorption of metal ions from the hydroxyapatite surface lattice.

3. Sorption of metal ions from the carbon surface.

Meat and bone meal combustion residues were found to contain over $56 \%$ of phosphate which could capture large quantities of aqueous $\mathrm{Pb}^{2+}$ ions in a few minutes with a $275 \mathrm{mg} / \mathrm{g}$ capacity. The ashes presented two beneficial actions in ecotoxicological studies: they not only neutralize lead toxicity but also act as a fertilizer.

Dried animal bones can also be used for $\mathrm{Zn}^{2+}$ removal from water and it was found that $10 \mathrm{mM}$ sulfuric acid can release more than $90 \%$ of the metal by desorption [37].

A Tunisian phosphate rock was activated by base and acid washings and found to have adequate heavy metal retention properties of between 12 and $15 \mathrm{mg} / \mathrm{g}$ for various metal cations [38, 39]. The activated raw material is expected to have a competitive edge over other commercial species. Low grade phosphorite deposits of sedimentary origin located in India are considered as waste because of their low phosphate values of $12.5 \%$ [40, 41]. They have been evaluated as eco-friendly and cost-effective sorbents for heavy metals. The used sorbents have been recycled in frit materials for glaze production in a zero waste concept.

\section{The Role of Organic Molecules on Heavy Metal Exchange}

Recent work has gained specific insight on the influence of organic molecules with metal complexing ability on the effectiveness of metal sequestration by HA [42]. It was shown that strong complexing ligands such as EDTA effectively stabilize the soluble form of metals and thereby decrease their capture by HA in the solid phase. This effect contrasts with the observation that various inorganic anions have no effect on heavy metal removal by adsorption on HA [43, 44].

Recent developments have led to the elaboration of composite materials wherein HA is embedded in a polymer matrix. An HA and polyurethane composite material [45] was made with $20 \%$ or $50 \%$ HA dispersed in the polymer foam to study lead ion uptake. It was found that higher HA contents had higher removal capability but slower removal rate. Also increased initial lead concentrations caused slower uptake rates. The dissolution of HA and precipitation of hydroxypyromorphite was the dominant mechanism at lower $\mathrm{pH}$ values of 2-3 for the incoming solution. The adsorption of $\mathrm{Pb}^{2+}$ ions on the $\mathrm{HA} /$ polyurethane composite surface and ion exchange reaction between $\mathrm{Ca}^{2+}$ of $\mathrm{HA}$ and $\mathrm{Pb}^{2+}$ in aqueous solution was dominant at higher $\mathrm{pH}$ values between 5 and 6 . Both mechanisms were found to compete at $\mathrm{pH} 4$. An HA/ cellulose composite was also studied for its exchange capacity and it was found that the cellulose matrix did not interfere with the HA-heavy metal reaction time or exchange capacity but helped in facilitating the watersorbent handling [46]. Up to $70 \mathrm{wt} \%$ HA could be incorporated in a polyacrylamide gel causing lower swelling in water, but also slower removal rate of $\mathrm{Pb}^{2+}$ ions. The removed amount of $\mathrm{Pb}^{2+}$ ion was nearly same, regardless of $\mathrm{pH}$ values of 2-5 [47].

In a study on porous HA granules which could remove aqueous lead ions at a rate of $0.5 \mathrm{mg} \mathrm{g}^{-1} \mathrm{~min}^{-1}$ it was observed that small lead phosphate aggregates were released from the HA sorbent together with calcium ions under some hydrodynamic flow conditions. It was reported that organic ligands tend to interfere with the water purification procedure [48]. 
In a study of the sorption of lead ions from simulated industrial wastewater onto Jordanian low-grade phosphate, it was found that increasing the concentration ratio of ligand to metal ion decreased the percentage removal of lead ions significantly for several organic carboxylic ligands [49]. Nevertheless, lead ions and lead-ligand complexes were observed to sorb on the phosphate ore $[50,51]$.

Wang et al. studied the effects of low molecular weight organic acids on the kinetics and adsorption isotherms of $\mathrm{Cu}^{2+}$ onto HA [52]. The maximal adsorption quantity decreased with increase in the logarithm of cumulative formation constants of $\mathrm{Cu}^{2+}$ and organic acids. Investigating the various species formed as a function of solution $\mathrm{pH}$, it was found that the effects of ligands on the uptake of copper depended on the stabilities and charges of the complex formed. The stronger the organic acid coordinated to copper, the more the metal quantity adsorbed on HA decreased.

\section{Remediation of Heavy Metal Contaminated Soils}

There are many examples of remediated soils that were contaminated with organic pollutants but there are few cases where heavy-metal polluted soils were treated, despite the fact that in most polluted sites in industrialized countries a variety of heavy metals are present. Toxic elements that remain untreated in soils and sediments represent a threat to surface and groundwater reserves. The persistent presence of mobile heavy metals in soils is a continuing challenge for authorities responsible for environmental protection [53, 54].

Usual remediation techniques involve ex-situ treatment of excavated material followed by land-filling and longterm monitoring following solidification/stabilization. This is not ecologically neutral to the landscapes and ecosystems involved. Alternative non destructive in situ treatment technologies are clean up options which can decrease the environmental disturbance and risk of exposure to living organisms. In situ stabilization is operated when leachable and bioavailable metals are transferred to less soluble forms that remain inert for long time periods. Chemical immobilization technologies can be combined with plant seeding and growth as a form of phytostabilization to attenuate contaminant dispersion via wind and hydrological processes. However, metal pollutions are also toxic to plants and the treatments used must specifically aim at reducing toxic metal mobility while maintaining needed mineral availability for plants in particular magnesium, iron and other vital oligo-elements [55-57].
The use of inexpensive minerals in remediation techniques is based on the well recognized role of stable species across a wide range of geological conditions. Clays, zeolites and apatites are attractive sequestering agents for in situ immobilization of toxic elements and reduction of risk associated with migration of potentially harmful species. Phosphates and particularly HA is known to be very effective in redistributing lead and other heavy metal ions into compounds more strongly withheld by soils. Reduced phytotoxicity goes with greater plant growth and lower concentrations of toxic elements in plant tissues. We will examine how HA and other phosphate chemical treatments leading to the formation of metal phosphates promote soil stabilization.

\section{The Role of HA in Immobilizing Soil Heavy Metals}

Contaminated soil has been dry mixed with HA with interesting results [58], but most studies rely on water present in soils for transfer of reactants or heavy metals to the more residual fractions of soils [59]. Sequential extraction procedures have demonstrated that exchangeable fraction of $\mathrm{Cu}$ and $\mathrm{Zn}$ in contaminated soils can be transformed into unavailable forms after chemical remediation [60]. The incorporation of heavy metals in apatites and the formation of silicate apatites have been compared to the formation of mineral reservoirs which can retain metals in their crystal structure following thermal treatment [61]. Biogenic apatite (fish bones) was compared to other phosphate sources and found to be less contaminated initially with heavy metals than processed or mined phosphate rock or fertilizers, but was found to be apparently more soluble, enhancing metal capture and providing a slow release of phosphate for continued long-term treatment [62].

Aqueous $\mathrm{Pb}^{2+}$ in lead contaminated soils was reduced after reaction with HA [63]. The hypothesis set forth to explain this result was that the $\mathrm{HA}$ dissolved and precipitated hydroxypyromorphite $\left[\mathrm{Pb}_{10}\left(\mathrm{PO}_{4}\right)_{6}(\mathrm{OH})_{2}\right]$ to effectively remove lead from the aqueous phase. More generally, it was found that lead chemical immobilization by any phosphate source could be related to the formation of pyromorphite $\mathrm{Pb}_{5}\left(\mathrm{PO}_{4}\right)_{3} \mathrm{X}$ where $\mathrm{X}=\mathrm{F}, \mathrm{Cl}, \mathrm{Br}, \mathrm{OH}$, the most stable environmental $\mathrm{Pb}$ compounds under a wide range of $\mathrm{pH}$ values [64]. Two morphological forms of pyromorphite $\mathrm{Pb}_{5}$ $\left(\mathrm{PO}_{4}\right)_{3} \mathrm{Cl}$ were observed in the presence of $\mathrm{Cl}^{-}$, phosphate, lead ions and goethite $\left(\alpha-\mathrm{Fe}(\mathrm{OH})_{3}\right)$ present in soils: incrustations, indicating direct reaction of $\mathrm{Pb}^{2+}$ and $\mathrm{Cl}^{-}$ions with $\mathrm{PO}_{4}{ }^{3-}$ adsorbed on goethite surface, and aggregates of pyromorphite crystals indicating that the reaction with $\mathrm{PO}_{4}{ }^{3-}$ ions took place in the volume of the solution [65]. The 
insoluble lead sulfide galena $(\mathrm{PbS})$ could be successfully treated by reacting with HA [66]. When galena, which is frequently found in mining wastes, is exposed to air atmosphere it becomes unstable causing it to become a labile source of $\mathrm{Pb}$ in soils. Transformation of unstable lead forms into sparingly soluble pyromorphite was confirmed in the presence of $\mathrm{HA}$. Conversion of soil $\mathrm{Pb}$ to chloropyromorphite $\left[\mathrm{Pb}_{5}\left(\mathrm{PO}_{4}\right)_{3} \mathrm{Cl}\right]$ was observed in a contaminated soil collected adjacent to a historical smelter when HA was added.[67]. Addition of hydroxyapatite to the soil caused a decrease in each of the first four more bio-available fractions of sequential extractable $\mathrm{Pb}$ and an increase in the recalcitrant extraction residue. Extended X-ray absorption fine structure (EXAFS) spectroscopy provided additional evidence that the change of soil $\mathrm{Pb}$ to pyromorphite was possible by simple amendments of hydroxyapatite to soil. The EXAFS approach illustrated that organically-complexed $\mathrm{Pb}$ was persistent in all HA amended soils, suggesting that an enriched soil organic carbon may be an inhibitory factor for pyromorphite transformations [68]. EXAFS was also used to provide evidence for the formation of several species during the immobilization of zinc ions by phosphate addition to contaminated dredged sediments.[69]. Both phosphate addition and calcination reduced leachability of heavy metals with the combined treatment achieving up to an $89 \%$ reduction. Due to the complexity of any soil matrix, the exact immobilization mechanisms following amendments have not been clarified, which could include precipitation, chemical adsorption and ion exchange, surface precipitation, formation of stable complexes with organic ligands, and redox reaction [70].

Special attention has been devoted to immobilization of radioactive metal ions with emphasis on the long-term performance of HA as reactive material for the removal of uranium in passive groundwater remediation systems [71, 72]. The formation of autunite $\mathrm{Ca}\left(\mathrm{UO}_{2}\right)_{2}\left(\mathrm{PO}_{4}\right)_{2}$ or chernikovite $\mathrm{H}_{2}\left(\mathrm{UO}_{2}\right) 2\left(\mathrm{PO}_{4}\right)_{2}$ was proposed as the low solubility uranium salts formed by reaction with HA [73]. EXAFS confirmed that uranium was phosphate bound to HA surfaces as an inner-sphere complex for relatively low U(VI) concentrations. Above 7000 ppm, chernikovite and autunite formations were detected by X-ray diffraction and fluorescence spectroscopy [26]. HA was found to be a strong sorbent for ${ }^{90} \mathrm{Sr}$, in soil for retardation of radionuclide migration. [74]. The effectiveness of HA, alone or with clay, was tested for $U$ retention by equilibrating with $\mathrm{CaCl}_{2}$ and subjecting to the Toxicity Characteristic Leaching Procedure (TCLP). HA and mixtures of HA with illite or zeolite, were highly effective in reducing $U$ extractability in both batch and leaching tests [75].

Poorly crystalline HA synthesized from gypsum waste or from incinerated poultry litter was described as advantageous when remediation targets vast amounts of contaminated soils. [76] Numerous natural and synthetic phosphates materials have been used for soil remediation including HA, biological apatite, rock phosphate, soluble phosphate fertilizers such as monoammonium phosphate, diammonium phosphate, phosphoric acid, phosphatic clay and mixtures [64, 77]. Most of the studies on heavy metal stabilization in soils were performed using various phosphorus-containing amendments, which reduce the metal mobility by precipitating insoluble mineral species [78-80]. All the observed results are compatible with available or predicted thermochemical data for the formation and stability of base metal phosphates in soils and sediments (1).

HA has been used on a large scale (90 tonnes) to make PRBs to successfully remediate groundwater containing several heavy metals [81].

\section{Role of HA as Permeable Reactive Barriers}

\section{Principles and Concept}

As an alternative to traditional pump-and-treat and dig-and treat methods for the remediation of contaminated groundwater, permeable reactive barrier is a relatively new in situ technology, and is attracting increased attention [82-84]

Permeable reactive barrier (PRB) technology has gained acceptance as an effective passive remediation strategy for the treatment of a variety of chlorinated organic and inorganic contaminants in groundwater by combinations of chemical, physical and biological treatments [85, 86].

In the subsurface the flow of the water is intercepted by a perpendicular "wall" of reactive materials that intercepts a plume of contaminated groundwater moving under the natural gradient and transforms the contaminant into an environmentally acceptable form. The goal is to have contaminant levels below target concentration at compliance points down gradient of the barrier. The barriers also prevent groundwater contaminants from migrating to uncontaminated aquifers, which may be difficult to locate and remedy [87-92].

The principle of the barrier is described in Fig. 3.

A benefit of its application is the large number of pollutants that can be treated often bringing their concentration below the detection limit. Moreover the site on the surface above the treated aquifer is available for other activities and can be economically re-used once the installation is concluded and during the remediation process. There is the possibility to treat waste plumes that are heterogeneous in composition and concentration and a reduction of costs $(\sim 50 \%)$ and energy compared to Pump and treat methodology could be achieve. In addition PRB 


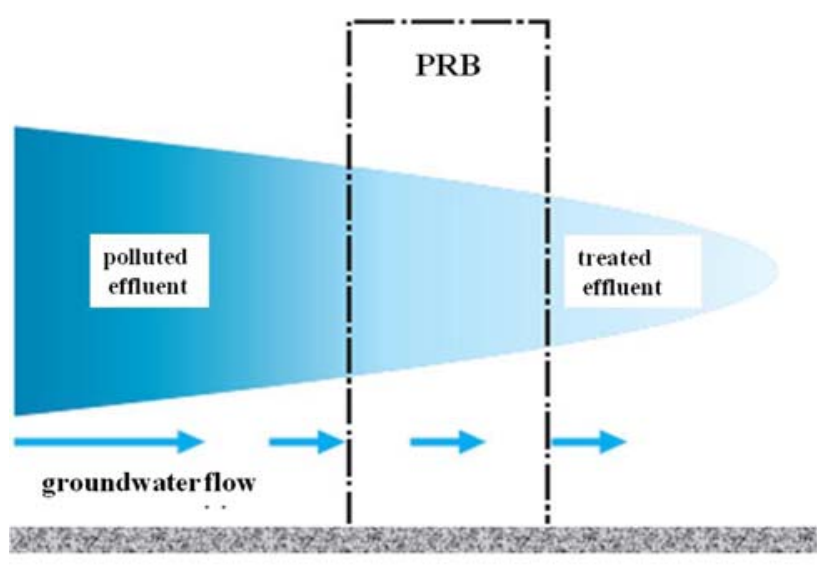

impermeable zone

Fig. 3 Principle of the Permeable Reactive Barrier

has lower impact to the rate of groundwater flow compared to Pump and treat.

PRB requires minimal maintenance because it operates in a totally passive manner. However, the four following characteristics need to be evaluated for the implementation a PRB: (1) hydrogeology, (2) contaminant loading, (3) geochemistry, and (4) microbiology. Hydrogeologic characterization must be done accurately as it determines groundwater flowpatterns and the distribution of the contaminant plume.

Performance, maintenance of PRB as well as the orientation of the efforts in research over the past decade have generated number of contributions in the literature [93-96].

\section{Material Used for the Design of PRBs}

Numerous studies have been performed in PRB. The PRB could be specific for dedicated contaminants. Several reactive media are used.

Zero-valent Iron $\left(\mathrm{Fe}^{0}\right)$, ZVI: currently is the most widespread material used for remediation of groundwater. The ZVI wall functions to remove chlorinated organic contaminants from the subsurface by reductively dechlorinating these species as contaminated ground water flows through the wall. While this is an extremely effective remediation technology for halogenated organic contaminants, ZVI walls are not able to sequester metal ions. Other media such as Calcite $\left(\mathrm{CaCO}_{3}\right)$ PRB are used for the removal of fluoride [97, 98], Polymer and silicate composites and Zeolite, periclase $(\mathrm{MgO})$, pecan shells, compost, peat moss, cottonseed meal, and lime, polysulfides, granulated activated charcoal (GAC), cottonseed meal and compost have been reported [97-105]. In the various cases investigated, Microbial activities have been pointed out to have a significant effect on the interaction between the barriers and the pollutants containing the plume, or microbial activity $[81,105,106]$.
The following paragraph will be focused on the use of HA as PRB material.

A number of literature references have reported the positive role of hydroxyapatite (Apatite) PRBs in the removal of a range of metals ions. The results of previous and ongoing work demonstrate that stabilization of contaminated soils and groundwater by apatite-group minerals has the potential to be a successful and widely applicable remediation strategy for metals and radionuclides [107-120].

Apatite-group minerals form naturally and are stable across a wide range of geological conditions for hundreds of millions of years [12, 121-127]. Work by Wright and others [122-124] investigated the trace-element composition of fossil apatite (teeth and bones) and sedimentary phosphorite deposits of various geological ages.

Metal ions are locked into the apatite structure with no subsequent desorption, leaching, or exchange, even in the face of diagenetic changes in the pore-water chemistry and $\mathrm{pH}$, high temperatures, and tectonic disruptions. More than 300 apatite-type minerals exist, with elements from the entire periodic table replacing $\mathrm{Ca}, \mathrm{P}$, and $\mathrm{OH}$ in the fundamental apatite crystal structure [81]. Their solubility products $\left(\mathrm{K}_{\mathrm{sp}}\right)$ are very low and vary from about $10^{-20}$ to $10^{-150}$

\section{Mechanisms [12, 109, 125-132]}

Two types of apatite are particularly concerned in PRB. Calcium hydroxyapatite with the formula $\mathrm{Ca}_{10}\left(\mathrm{PO}_{4}\right)_{6}$ $(\mathrm{OH})_{2}$ and $\mathrm{Ca}_{10-\mathrm{x}} \mathrm{Na}_{\mathrm{x}}\left(\mathrm{PO}_{4}\right)_{6-\mathrm{x}}\left(\mathrm{CO}_{3}\right)_{\mathrm{x}}(\mathrm{OH})_{2}$ so called Apatite (II), a particular form of apatite generated as a waste product from fish industry. The mechanism described for the uptake and stabilization of metal and radionuclides is dissolution and precipitation illustrated as follows with uranium and lead:

- Stabilisation of uranium:

$\mathrm{Ca}_{5}\left(\mathrm{PO}_{4}\right)_{3} \mathrm{OH} \Leftrightarrow 5 \mathrm{Ca}^{2+}+3 \mathrm{PO}_{4}^{3-}+\mathrm{OH}^{-}$

$2 \mathrm{UO}_{2}^{2+}+\mathrm{Ca}^{2+}+2 \mathrm{PO}_{4}^{3-} \Leftrightarrow \mathrm{Ca}\left(\mathrm{UO}_{2}\right)_{2}\left(\mathrm{PO}_{4}\right)_{2}$

$\mathrm{Ca}\left(\mathrm{UO}_{2}\right)_{2}\left(\mathrm{PO}_{4}\right)_{2}$ has a low solubility product, $\log \mathrm{K}_{\mathrm{sp}}=$ $-45.5$

- Stabilisation of lead:

$$
\begin{aligned}
\mathrm{Ca}_{10-x} \mathrm{Na}_{x}\left(\mathrm{PO}_{4}\right)_{6-x}\left(\mathrm{CO}_{3}\right)_{x}(\mathrm{OH})_{2}+14 \mathrm{H}^{+} \rightarrow \\
(10-x) \mathrm{Ca}^{2+}+x \mathrm{Na}^{+}+(6-x)\left[\mathrm{H}_{2}\left(\mathrm{PO}_{4}\right)\right]^{-} \\
+x \mathrm{H}_{2} \mathrm{CO}_{3}+2 \mathrm{H}_{2} \mathrm{O} \\
10 \mathrm{~Pb}^{2+}+6 \mathrm{H}_{2}\left(\mathrm{PO}_{4}\right)^{-}+2 \mathrm{OH}^{-} \\
\rightarrow \mathrm{Pb}_{10}\left(\mathrm{PO}_{4}\right)_{6}(\mathrm{OH})_{2}+12 \mathrm{H}^{+}
\end{aligned}
$$

This mechanism is the same identified in solution as described in previous sections. The degree of protonation 
of the phosphate and carbonate in the intermediate reactions depends upon the $\mathrm{pH}$. The above example is for the typical range of acid mine drainage, i.e., $\mathrm{pH}$ between 3 and 6. Reactions (1) and (3) do not necessarily lead to reaction (2) and (4). However, because the apatite provides a small but constant supply of phosphate to solution, if $\mathrm{Pb}^{2+}$ is in solutions contacting the apatite, then reactions (3) and (4) will take place. Apatite II dissolution is a strong $\mathrm{pH}$ buffering reaction, buffering around neutral (6.5-7) through its $\mathrm{PO}_{4}^{3-}, \mathrm{OH}^{-}$and substituted $\mathrm{CO}_{3}^{2-}$ groups.

Other mechanisms such as ion exchange and the formation of amorphous solids, surface complexation or chemisorption are also reported in the literature to explain the process of removal of the transition metals in particular, through its uncompensated phosphate and hydroxyl surface groups.

The metal-phosphate phase is very stable over geological time because of its low solubility products $\left(\mathrm{K}_{\mathrm{sp}}\right)$. These metal-phosphate products are thermodynamically stable over a broad range of environmental conditions, and precipitate rapidly, thus ensuring long term immobilization of metal pollutants. Metals and apatite react very quickly at the molecular scale, but at a macroscopic dimension, limiting parameters like grain size, porosity, flow rate, barrier design, influence the efficiency with which dissolved metals come into contact with the surface of the reactive media.

The use of Apatite has several advantages. In fact, Apatite can sequester most heavy metals and radionuclides which then precipitate as mineral phases in which the metals are not bioavailable. Apatite is one of the best nonspecific surface sorbent for species that do not precipitate as a separate phase and is the most cost-effective reactive media for most metals and radionuclides. Apatite can be mixed into contaminated soil or waste, emplaced in PRB or used as a disposal liner and can be combined with most other reactive media e.g., grout, calcite, zeolite, polymers, bentonite, zero valent iron, and other remediation technologies, e.g., bioremediation, etc.

\section{Conclusion}

Phosphate chemistry can be used to develop environmentally friendly processes for pollution clean-up and valorization of brownfields and soils. Treated sediments with heavy metals locked in a stable insoluble structure could be valorized and work is in progress in this direction. Water purification and recycling is becoming an important issue and apatite chemistry will contribute to the valorization effort in the near future. From the scientific results gathered by much laboratory work it is becoming clear that processes with phosphates, apatite formation and use combined with thermal treatments are ready for industrial pilot developments.

\section{References}

1. Nriagu, J.O.: Formation and stability of base metal phosphates in soils and sediments. In: Nriagu, J.O., Moore, P.B. (eds.) Phosphate Minerals. Springer-Verlag, London, UK (1984)

2. Jaynes, W.F., Moore Jr., P.A., Miller, D.M.: Solubility and ion activity products of calcium phosphate minerals. J. Environ. Qual. 28(2), 530-536 (1999)

3. Amrah-Bouali, S., Rey, C., Lebugle, A., Bernache, D.: Surface modifications of hydroxyapatite ceramics in aqueous media. Biomaterials 15(4), 269-272 (1994)

4. Suzuki, T., Hatsushika, T., Hayakawa, Y.: Synthetic hydroxyapatites employed as inorganic cation-exchangers. J. Chem. Soc., Faraday Trans. 1 77(5), 1059-1062 (1981)

5. Suzuki, T., Hatsushika, T., Miyake, M.: Synthetic hydroxyapatites as inorganic cation exchangers. Part 2. J. Chem. Soc., Faraday Trans. 1 78(12), 3605-3611 (1982)

6. Suzuki, T., Ishigaki, K., Miyake, M.: Synthetic hydroxyapatites as inorganic cation exchangers. Part 3. Exchange characteristics of lead ions $\left(\mathrm{Pb}^{2+}\right)$. J. Chem. Soc., Faraday Trans. 1 80(11), 3157-3165 (1984)

7. Bailliez, S., Nzihou, A., Bèche, E., Flamant, G.: Removal of lead $(\mathrm{Pb})$ by hydroxyapatite sorbent. Proc. Safety Environ. Protec. 82(2B), 175-180 (2004)

8. Marchat, D., Bernache-Assollant, D., Champion, E.: Cadmium fixation by synthetic hydroxyapatite in aqueous solution-thermal behavior. J. Hazard. Mater. 139(3), 453-460 (2007)

9. Chen, X., Wright, J.V., Conca, J.L., Peurrung, L.M.: Effects of $\mathrm{pH}$ on heavy metal sorption on mineral apatite. Environ. Sci. Technol. 31(3), 624-631 (1997)

10. Mavropoulos, E., Rossi, A.M., Costa, A.M., Perez, C.A.C., Moreira, J.C., Saldanha, M.: Studies on the mechanisms of lead immobilization by hydroxyapatite. Environ. Sci. Technol. 36(7), 1625-1629 (2002)

11. Suzuki, Y., Takeuchi, Y.: Uptake of a few divalent heavy metal ionic species by a fixed bed of hydroxyapatite particles. J. Chem. Eng. Jpn. 27(5), 571-576 (1994)

12. Manecki, M., Maurice, P.A., Traina, S.J.: Kinetics of aqueous $\mathrm{Pb}$ reaction with apatites. Soil Sci. 165(12), 920-933 (2000)

13. Manecki, M., Maurice, P.A., Traina, S.J.: Uptake of aqueous $\mathrm{Pb}$ by $\mathrm{Cl}^{-}, \mathrm{F}^{-}$, and $\mathrm{OH}^{-}$apatites: mineralogic evidence for nucleation mechanisms. Am. Miner. 85(7-8), 932-942 (2000)

14. Lower, S.K., Maurice, P.A., Traina, S.J., Carlson, E.H.: Aqueous $\mathrm{Pb}$ sorption by hydroxylapatite: applications of atomic force microscopy to dissolution, nucleation, and growth studies. Am. Miner. 83(1-2), 147-158 (1998)

15. Stötzel, C., Müller, F.A., Reinert, F., Niederdraenk, F., Barralet, J.E., Gbureck, U.: Ion adsorption behaviour of hydroxyapatite with different crystallinities. Colloids Surf. B Biointerfaces 74(1), 91-95 (2009)

16. Takeuchi, Y., Arai, H.: Hironori Removal of coexisting $\mathrm{Pb}^{2+}$, $\mathrm{Cu}^{2+}$ and $\mathrm{Cd}^{2+}$ ions from water by addition of hydroxyapatite powder. J. Chem. Eng. Jpn. 23(1), 75-80 (1990)

17. Hashimoto, Y., Sato, T.: Removal of aqueous lead by poorly-crystalline hydroxyapatites. Chemosphere 69(11), 1775-1782 (2007)

18. Xu, Y., Schwartz, F.W.: Lead immobilization by hydroxyapatite in aqueous solutions. J. Contam. Hydrol. 15(3), 187-206 (1994)

19. Sugiyama, S., Ichii, T., Hayashi, H., Tomida, T.: Lead immobilization by non-apatite-type calcium phosphates in aqueous solutions. Inorg. Chem. Commun. 5(2), 156-158 (2002) 
20. Lusvardi, G., Malavasi, G., Menabue, L., Saladini, M.: Removal of cadmium ion by means of synthetic hydroxyapatite. Waste Manag. 22(8), 853-857 (2002)

21. Monteil-Rivera, F., Fedoroff, M.: Sorption of inorganic species on apatites from aqueous solutions. Encyclopedia Surf. Colloid Sci. 1, 1-26 (2002)

22. Corami, A., D’Acapito, F., Mignardi, S., Ferrini, V.: Removal of $\mathrm{Cu}$ from aqueous solutions by synthetic hydroxyapatite: EXAFS investigation. Mater. Sci. Eng. B 149(2), 209-213 (2008)

23. Corami, A., Mignardi, S., Ferrini, V.: Cadmium removal from single- and multi-metal $(\mathrm{Cd}+\mathrm{Pb}+\mathrm{Zn}+\mathrm{Cu})$ solutions by sorption on hydroxyapatite. J. Colloid Interface Sci. 317(2), 402-408 (2008)

24. Krestou, A., Xenidis, A., Panias, D.: Mechanism of aqueous uranium(VI) uptake by hydroxyapatite. Miner. Eng. 17(3), 373381 (2004)

25. Fuller, C.C., Bargar, J.R., Davis, J.A.: Molecular-scale characterization of uranium sorption by bone apatite materials for a permeable reactive barrier demonstration. Environ. Sci. Technol. 37(20), 4642-4649 (2003)

26. Fuller, C.C., Bargar, J.R., Davis, J.A., Piana, M.J.: Mechanisms of uranium interactions with hydroxyapatite: implications for groundwater remediation. Environ. Sci. Technol. 36(2), 158165 (2002)

27. Shashkova, I.L., Rat'ko, A.I., Kitikova, N.V.: Removal of heavy metal ions from aqueous solutions by alkaline-earth metal phosphates. Colloids Surf. A 160(3), 207-215 (1999)

28. Sugiyama, S., Fujisawa, M., Koizumi, T., Tanimoto, S., Kawashiro, K., Tomida, T., Hayashi, H.: Immobilization of aqueous heavy metal cations with phosphates and sulfates. Bull. Chem. Soc. Jpn. 76(12), 2419-2422 (2003)

29. Deydier, E., Guilet, R., Cren, S., Pereas, V., Mouchet, F., Gauthier, L.: Evaluation of meat and bone meal combustion residue as lead immobilizing material for in situ remediation of polluted aqueous solutions and soils: "Chemical and ecotoxicological studies". J. Hazard. Mater. 146(1-2), 227-236 (1999)

30. Cheung, C.W., Porter, J.F., McKay, G.: Removal of $\mathrm{Cu}(\mathrm{II})$ and $\mathrm{Zn}$ (II) ions by sorption onto bone char using batch agitation. Langmuir 18(3), 650-656 (2002)

31. Aoki, K., Nakata, H., Matsumoto, K., Sawa, H.: Removal of $\mathrm{Pb}^{2+}$ and $\mathrm{Cd}^{2+}$ Ions by hydroxyapatite separated from scales of fish Zairyo. J. Soc. Mater. Sci. Jpn. 46(9), 1009-1010 (1997)

32. Giammar, D.E., Xie, L., Pasteris, J.D.: Immobilization of lead with nanocrystalline carbonated apatite present in fish bone. Environ. Eng. Sci. 25(5), 725-735 (2008)

33. Ozawa, M., Kanahara, S.: Removal of aqueous lead by fish-bone waste hydroxyapatite powder. J. Mater. Sci. 40(4), 1037-1038 (2005)

34. Hettiarachchi, G.M., Pierzynski, G.M., Ransom, M.D.: In situ stabilization of soil lead using phosphorus. J. Environ. Qual. 30, 1214-1221 (2001)

35. Thomson, B.M., Smith, C.L., Busch, R.D., Siegel, M.D., Baldwin, C.: Removal of metals and radionuclides using apatite and other natural sorbents. J. Environ. Eng. 129(6), 492-499 (2003)

36. Dybowska, A., Manning, D.A.C., Collins, M.J., Wess, T., Woodgate, S., Valsami-Jones, E.: An evaluation of the reactivity of synthetic and natural apatites in the presence of aqueous metals. Sci. Total Environ. 407(8), 2953-2965 (2009)

37. Banat, F., Al-Asheh, S., Mohai, F.: Batch zinc removal from aqueous solution using dried animal bones. Sep. Purif. Technol. 21(1-2), 155-164 (2000)

38. Elouear, Z., Amor, R.B., Bouzid, J., Boujelben, N.: Use of phosphate rock for the removal of $\mathrm{Ni}^{2+}$ from aqueous solutions:
Kinetic and thermodynamics studies. J. Environ. Eng. 135(4), 259-265 (2009)

39. Elouear, Z., Bouzid, J., Boujelben, N., Feki, M., Jamoussi, F., Montiel, A.: Heavy metal removal from aqueous solutions by activated phosphate rock. J. Hazard. Mater. 156(1-3), 412-420 (2008)

40. Prasad, M., Xu, H.-Y., Saxena, S.: Multi-component sorption of $\mathrm{Pb}(\mathrm{II}), \mathrm{Cu}(\mathrm{II})$ and $\mathrm{Zn}$ (II) onto low-cost mineral adsorbent. J. Hazard. Mater. 154(1-3), 221-229 (2008)

41. Saxena, S., D'Souza, S.F.: Heavy metal pollution abatement using rock phosphate mineral. Environ. Int. 32(2), 199-202 (2006)

42. Hadioui, M., Mecherri, M.O., Sharrock, P.: Silica gel and hydroxyapatite composites with ormosils for heavy metal removal from water. AIChE Annual Meeting, Conf. Proc., 6 p. (2006)

43. Ma, L.Q.: Factors influencing the effectiveness and stability of aqueous lead immobilization by hydroxyapatite. J. Environ. Qual. 25(6), 1420-1429 (1996)

44. Ma, Q.Y., Logan, T.J., Traina, S.J., Ryan, J.A.: Effects of $\mathrm{NO}_{3}{ }^{-}$, $\mathrm{Cl}^{-}, \mathrm{F}^{-}, \mathrm{SO}_{4}{ }^{2-}$, and $\mathrm{CO}_{3}{ }^{2-}$ on $\mathrm{Pb}^{2+}$ immobilization by hydroxyapatite. Environ. Sci. Technol. 28(3), 408-418 (1994)

45. Jang, S.H., Min, B.G., Jeong, Y.G., Lyoo, W.S., Lee, S.C.: Removal of lead ions in aqueous solution by hydroxyapatite/ polyurethane composite foams. J. Hazard. Mater. 152(3), 12851292 (2008)

46. Choi, S., Jeong, Y.: The removal of heavy metals in aqueous solution by hydroxyapatite/cellulose composite. Fibers Polym. 9(3), 267-270 (2008)

47. Jang, S.H., Jeong, Y.G., Min, B.G., Lyoo, W.S., Lee, S.C.: Preparation and lead ion removal property of hydroxyapatite/ polyacrylamide composite hydrogels. J. Hazard. Mater. 159(23), 294-299 (2008)

48. Hadioui, M., Sharrock, P., Mecherri, M.O., Brumas, V., Fiallo, M.: Reaction of lead ions with hydroxylapatite granules. Chem. Pap. 62(5), 516-521 (2008)

49. Kandah, M.I.: The potential use of low-grade phosphate rocks as adsorbent. Chem. Eng. Technol. 25(9), 921-924 (2002)

50. Sarioglu, M., Atay, Ü.A., Cebeci, Y.: Removal of copper from aqueous solutions by phosphate rock. Desalination 181(1-3), 303-311 (2005)

51. Mouflih, M., Aklil, A., Sebti, S.: Removal of lead from aqueous solutions by activated phosphate. J. Hazard. Mater. 119(1-3), 183-188 (2005)

52. Wang, Y.J., Chen, J.H., Cui, Y.X., Wang, S.Q., Zhou, D.M.: Efects of low molecular weight organic acids on $\mathrm{Cu}$ (II) adsorption onto hydroxyapatite nanoparticles. J. Hazard. Mater. 162, 1135-1140 (2009)

53. Dermont, G., Bergeron, M., Mercier, G., Metal-contaminated soils: remediation practices and treatment technologies. Pract. Period. Hazard. Toxic Radioactive Waste Manag. 12(3), 188209 (2008)

54. Manning, D.A.C.: Phosphate minerals, environmental pollution and sustainable agriculture. Elements 4(2), 105-108 (2008)

55. Chen, S., Xu, M., Ma, Y., Yang, J.: Evaluation of different phosphate amendments on availability of metals in contaminated soil. Ecotoxicol. Environ. Saf. 67(2), 278-285 (2007)

56. Keller, C., Marchetti, M., Rossi, L., Lugon-Moulin, N.: Reduction of cadmium availability to tobacco (Nicotiana tabacum) plants using soil amendments in low cadmium-contaminated agricultural soils: a pot experiment. Plant Soil 276(1-2), 69-84 (2005)

57. Boisson, J., Ruttens, A., Mench, M., Vangronsveld, J.: Evaluation of hydroxyapatite as a metal immobilizing soil additive for the remediation of polluted soils. Part 1 . Influence of 
hydroxyapatite on metal exchangeability in soil, plant growth and plant metal accumulation. Environ. Pollut. 104(2), 225-233 (1999)

58. Montinaro, S., Concas, A., Pisu, M., Cao, G.: Immobilization of heavy metals in contaminated soils through ball milling with and without additives. Chem. Eng. J. 142(3), 271-284 (2008)

59. Ciardelli, M.C., Xu, H., Sahai, N.: Role of Fe(II), phosphate, silicate, sulfate, and carbonate in arsenic uptake by coprecipitation in synthetic and natural groundwater. Water Res. 42(3), 615-624 (2008)

60. Fawzy, E.M.: Soil remediation using in situ immobilization techniques. Chem. Ecol. 24(2), 147-156 (2008)

61. Pöllmann, H.: Immobilisation of toxic elements in mineral reservoirs. Australasian Institute of Mining and Metallurgy Publication Series, pp. 63-71 (2008)

62. Knox, A.S., Kaplan, D.I., Paller, M.H.: Phosphate sources and their suitability for remediation of contaminated soils. Sci. Total Environ. 357(1-3), 271-279 (2006)

63. Ma, Q.Y., Traina, S.J., Logan, T.J., Ryan, J.A.: In situ lead immobilization by apatite. Environ. Sci. Technol. 27(9), 18031810 (1993)

64. Miretzky, P., Fernandez-Cirelli, A.: Phosphates for Pb immobilization in soils: a review. Environ. Chem. Lett. 6(3), 121-133 (2008)

65. Manecki, M., Bogucka, A., Bajda, T., Borkiewicz, O.: Decrease of $\mathrm{Pb}$ bioavailability in soils by addition of phosphate ions. Environ. Chem. Lett. 3(4), 178-181 (2006)

66. Zhang, P., Ryan, J.A.: Formation of chloropyromorphite from Galena $(\mathrm{PbS})$ in the presence of hydroxyapatite. Environ. Sci. Technol. 33(4), 618-624 (1999)

67. Ryan, J.A., Zhang, P., Hesterberg, D., Chou, J., Sayers, D.E.: Formation of chloropyromorphite in a lead-contaminated soil amended with hydroxyapatite. Environ. Sci. Technol. 35(18), 3798-3803 (2001)

68. Hashimoto, Y., Takaoka, M., Oshita, K., Tanida, H.: Incomplete transformations of $\mathrm{Pb}$ to pyromorphite by phosphate-induced immobilization investigated by X-ray absorption fine structure (XAFS) spectroscopy. Chemosphere 76(5), 616-622 (2009)

69. Ndiba, P., Axe, L., Boonfueng, T.: Heavy metal immobilization through phosphate and thermal treatment of dredged sediments. Environ. Sci. Technol. 42(3), 920-926 (2008)

70. Qun, W.L., Lei, L.U.O., Yi-bing, Ma., Dong-pu, W.E.I., Luo, H.U.A.: In situ immobilization remediation of heavy metalscontaminated soils: a review. Chin. J. Appl. Ecol. 20(5), 12141222 (2009)

71. Simon, F.-G., Biermann, V., Segebade, C., Hedrich, M.: Behaviour of uranium in hydroxyapatite-bearing permeable reactive barriers: Investigation using ${ }^{237} \mathrm{U}$ as a radioindicator. Sci. Total Environ. 326(1-3), 249-256 (2004)

72. Raicevic, S., Wright, J.V., Veljkovic, V., Conca, J.L.: Theoretical stability assessment of uranyl phosphates, apatites: selection of amendments for in situ remediation of uranium. Sci. Total Environ. 355(1-3), 13-24 (2006)

73. Simon, F.-G., Biermann, V.: Groundwater remediation using permeable reactive barriers. Land Contam. Reclam. 15(1), 3139 (2007)

74. Moore, R.C., Sanchez, C., Holt, K., Zhang, P., Xu, H., Choppin, G.R.: Formation of hydroxyapatite in soils using calcium citrate and sodium phosphate for control of strontium migration. Radiochim. Acta 92(9-11), 719-723 (2004)

75. Seaman, J.C., Meehan, T., Bertsch, P.M.: Immobilization of cesium-137 and uranium in contaminated sediments using soil amendments. J. Environ. Qual. 30(4), 1206-1213 (2001)

76. Hashimoto, Y., Taki, T., Sato, T.: Sorption of dissolved lead from shooting range soils using hydroxyapatite amendments synthesized from industrial byproducts as affected by varying pH conditions. J. Environ. Manage. 90(5), 1782-1789 (2009)

77. Abu Al-Rub, F.A.: Sorption of lead ions from simulated industrial wastewater onto Jordanian low-grade phosphate. Adsorp. Sci. Technol. 22(2), 165-179 (2004)

78. Kumpiene, J., Lagerkvist, A., Maurice, C.: Stabilization of As, $\mathrm{Cr}, \mathrm{Cu}, \mathrm{Pb}$ and $\mathrm{Zn}$ in soil using amendments - a review. Waste Manage. 28(1), 215-225 (2008)

79. Thawornchaisit, U., Polprasert, C.: Evaluation of phosphate fertilizers for the stabilization of cadmium in highly contaminated soils. J. Hazard. Mater. 165(1-3), 1109-1113 (2009)

80. Cao, X., Wahbi, A., Ma, L., Li, B., Yang, Y.: Immobilization of $\mathrm{Zn}, \mathrm{Cu}$, and $\mathrm{Pb}$ in contaminated soils using phosphate rock and phosphoric acid. J. Hazard. Mater. 164(2-3), 555-564 (2009)

81. Conca, J.L., Wright, J.: An Apatite II permeable reactive barrier to remediate groundwater containing $\mathrm{Zn}, \mathrm{Pb}$ and $\mathrm{Cd}$. Appl. Geochem. 21(8), 1288-1300 (2006)

82. Wilkin, R.T., Acree, S.D., Ross, R.R., Beak, D.G., Lee, T.R.: Performance of a zerovalent iron reactive barrier for the treatment of arsenic in groundwater: Part 1. Hydrogeochemical studies. J. Contam. Hydrol. 106(1-2), 1-14 (2009)

83. O'Hannesin, S., Gillham, R.W.: Long-term performance of an in situ"ironwall" for remediation of VOCs. Ground Water 36, 164-170 (1998)

84. Blowes, D.W., Ptacek, C.J., Benner, S.G., McRae, C.W.T., Bennett, T.A., Puls, R.W.: Treatment of inorganic contaminants using permeable reactive barriers. J. Contam. Hydrol. 45, 123137 (2000)

85. Lee, J., Graettinger, A.J., Moylan, J., Reeves, H.W.: Directed site exploration for permeable reactive barrier design. J. Hazard. Mater. 162, 222-229 (2009)

86. Gavaskar, A.R.: Design and construction technique for permeable reactive barriers. J. Hazard. Mater. 68, 41-71 (1999)

87. National Research Council: Alternatives for Ground Water Cleanup. National Academy Press, Washington, DC (1994)

88. U.S. Environmental Protection Agency: Permeable Reactive Barrier Technologies for Contaminant Remediation. EPA/600R98/125. Office of Solid Waste and Emergency Response, Washington, DC (1998)

89. Kamolpornwijit, W., Liang, L., West, O.R., Moline, G.R., Sullivan, A.B.: Preferential flow path development and its influence on long-term PRB performance: column study. J. Contam. Hydrol. 66, 161-178 (2003)

90. Korte, N.E.: Zero-valent Iron Permeable Reactive Barriers: A Review of Performance. Environmental Sciences Division Publication 5056. Oak Ridge National Laboratory, Tennessee (2001)

91. USEPA: Capstone report on the application, monitoring, and performance of permeable reactive barriers for ground-water remediation; Performance evaluations at two sites, EPA/600/R03/045a, p. 1. National Risk Management Research Laboratory, Cincinnati, $\mathrm{OH}$ (2003)

92. Liang, L., Moline, G.R., Kamolpornwijit, W., West, O.R.: Influence of hydrochemical processes on zero-valent iron reactive barrier performance: a field investigation. J. Contam. Hydrol. 80, 71-91 (2005)

93. Li, L., Benson, C.H., Lawson, E.M.: Modeling porosity reductions caused by mineral fouling in continuous-wall permeable reactive barriers. J. Contam. Hydrol. 83, 89-121 (2006)

94. Harrup, M.K., Jones, M.G., Polson, L., White, B.: Polymer/silicate composites: new materials for subsurface permeable reactive barriers. J. Sol-Gel. Sci. Technol. 47, 243-251 (2008)

95. USEPA: A listing of government supported full-scale remediation sites is found in the following government document: EPA/ 542/R-99/002. United States Environmental Protection Agency 
Office of Solid Waste and Emergency Response, Technology Innovation Office, Washington, DC (1999)

96. Benner, S.G., Blowes, D.W., Ptacek, C.J.: A full-scale porous reactive wall for the prevention of acid mine drainage. Ground Water Monit. Rem. 17, 99-107 (1997)

97. Turner, B.D., Binning, P., Sloan, S.: The CO2 enhanced removal of fluoride using a calcite permeable reactive barrier. Geochim. Cosmochim. Acta 68(11S), A460 (2004)

98. Turner, B.D., Binning, P.J., Sloan, S.W.: A calcite permeable reactive barrier for the remediation of Fluoride from spent potliner (SPL) contaminated groundwater. J. Contam. Hydrol. 95, 110-120 (2008)

99. Powel, R.M., Puls, R.W., Blowes, D.W., Gillham, R.W., Schultz, D.: EPA/600/R-98/125, p. 114. United States Environmental Protection Agency Center for Environmental Research Information, Cincinati (1998)

100. Blowes, D.W., Ptacek, C.J., Jambor, J.L.: In situ remediation of $\mathrm{Cr}(\mathrm{VI})$-contaminated groundwater using permeable reactive walls: laboratory studies. Environ. Sci. Technol. 31, 3348-3357 (1997)

101. Tratnyek, P.G., Johnson, T.L., Scherer, M.M., Eykholt, G.R.: Remediating groundwater with zero-valent metals: kinetic considerations in barrier design. Ground Water Monit. Rem. 17, 108-114 (1997)

102. Puls, R.W., Blowes, D.W., Gillham, R.W.: Long-term performance monitoring for a permeable reactive barrier at the US Coast Guard Support Center, Elizabeth City, North Carolina. J. Hazard. Mater. 68, 109-124 (1999)

103. Logan, B.E.: Assessing the outlook for perchlorate remediation. Environ. Sci. Technol. 35, 483a-487a (2001)

104. Goldstein, K.J., O’Hannesin, S., McDonald, S., Gaule, C., Anderson, G.A., Marsh, R., Senick, M.: Dual permeable reactive barrier walls remediate chlorinated hydrocarbon contamination. In: Wickramanayake, G.B., Gavaskar, A.R., Chen, S.C. (eds.) Remediation of Chlorinated and Recalcitrant Compounds, vol. 6, pp. 273-280. Battelle Press, Columbus, Ohio (2000)

105. Naftz, D.L., Fuller, C.C., Davis, J.A., Piana, M.J., Morrison, S.J., Freethey, G.W., Rowland, R.C.: Field demonstration of PRBs to control uranium contamination in groundwater. In: Wickramanayake, G.B., Gavaskar, A.R., Chen, S.C. (eds.) Remediation of Chlorinated and Recalcitrant Compounds, vol. 6, pp. 281-290. Battelle Press, Columbus, Ohio (2000)

106. Starr, R.C., Cherry, J.A.: In situ remediation of contaminated groundwater: the funnel-and-gate system. Ground Water 32, 456-476 (1994)

107. McArthur, J.M., Sahami, A.R., Thirwall, M., Hamilton, P.J., Osborn, A.O.: Dating phosphogenesis with $\mathrm{Sr}$ isotopes. Geochim. Cosmochim. Acta 54, 1343-1352 (1990)

108. Ma, Q.Y., Traina, S.J., Logan, T.J.: In situ lead immobilization by apatite. Environ. Sci. Technol. 27, 1803-1810 (1993)

109. Ma, Q.Y., Logan, T.J., Traina, S.J.: Lead immobilization from aqueous solutions and contaminated soils using phosphate rocks. Environ. Sci. Technol. 29, 1118-1126 (1995)

110. Ruby, M.V., Davis, A., Nicholson, A.: In situ formation of lead phosphates in soils as a method to immobilize lead. Environ. Sci. Technol. 28, 646-654 (1994)

111. Stanforth, R., Chowdhury, A.: In situ stabilization of lead contaminated soil. In: Federal Environmental Restoration III and Waste Minimization II Conference Proceedings, New Orleans (1994)

112. Xu, Y., Schwartz, F.W.: Lead immobilization by ydroxyapatite in aqueous solutions. J. Contam. Hydrol. 15, 187-206 (1994)

113. Chen, X.-B., Wright, J.V., Conca, J.L., Peurrung, L.M.: Effects of $\mathrm{pH}$ on heavy metal sorption on mineral apatite. Environ. Sci. Technol. 31, 624-631 (1997)
114. Basta, N.T., McGowen, S.L.: Evaluation of chemical immobilization treatments for reducing heavy metal transport in a smelter-contaminated soil. Environ. Pollut. 127, 73-82 (2004)

115. Eighmy, T.T., Crannell, B.S., Butler, L.G., Cartledge, F.K., Emery, E.F., Oblas, D., Krzanowski, J.E., Eusden Jr., J.D., Shaw, E.L., Francis, C.A.: Heavy metal stabilization in municipal solid waste combustion dry scrubber residue using soluble phosphate. Environ. Sci. Technol. 31, 3330-3338 (1997)

116. Zhang, P., Ryan, J., Yang, J.: In vitro soil Pb solubility in the presence of hydroxyapatite. Environ. Sci. Technol. 32, 27632768 (1998)

117. Manecki, M., Maurice, P.A., Traina, S.J.: Kinetics of aqueous $\mathrm{Pb}$ reaction with apatites. Soil Sci. 165, 920-933 (2000)

118. Wright, J., Rice, K.R., Murphy, B., Conca, J.L.: PIMS using Apatite IITM: how it works to remediate soil and water. In: Proceedings of the Conference on Sustainable Range Management. Available from: ISBN 1-57477-144-2, B4-05 (2004)

119. Wright, J., Rice, K.R., Murphy, B., Conca, J.L.: PIMS remediation of $\mathrm{Pb}$-contaminated soil at Camp Stanley, Texas. In: Proceedings of the Conference on Sustainable Range Management. Available from: ISBN 1-57477-144-2, B4-04 (2004)

120. Wright, J., Conca, J.L., Slater, A.F.: PIMS with apatite II: a field scale demonstration on a lead contaminated soil. In: Al-Tabbaa, A., Stegemann, J.A. (eds.) Stabilisation/Solidification Treatment and Remediation. Taylor and Francis Group, London (2005). ISBN $041537460 \mathrm{X}$ (4)

121. Nriagu, J.O.: Lead orthophosphates. IV. Formation and stability in the environment. Geochim. Cosmochim. Acta 38, 887-898 (1974)

122. Wright, J.: Conodont apatite: structure and geochemistry. In: Carter, J. (ed.) Skeletal Biomineralization: Patterns Processes and Evolutionary Trends, pp. 445-459. Van Nostrand Reinhold, New York (1990)

123. Wright, J., Seymour, R.S., Shaw, H.F.: REE and Nd isotopes in conodont apatite: variations with geological age and depositional environment. In: Clark, D.L. (ed.) Conodont Biofacies and Provincialism, pp. 325-340. Geol. Soc. Am. Spec. Pap. 196 (1984)

124. Wright, J., Schrader, H., Holser, W.T.: Paleoredox variations in ancient oceans recorded by rare earth elements in fossil apatite. Geochim. Cosmochim. Acta 51, 631-644 (1987)

125. Chen, X., Wright, J., Conca, J.L., Peurrung, L.M.: Evaluation of heavy metal remediation using mineral apatite. Water Air Soil Pollut. 98, 57-78 (1997)

126. Wright, J., Rice, K. R., Murphy, B., Conca, J.L.: PIMS using Apatite $\mathrm{II}^{\mathrm{TM}}$ : how it works to remediate soil and water. Sustainable Range Management-2004. In: Proceedings of the Conference on Sustainable Range Management, January 5-8, 2004, New Orleans, ISBN 157477-144-2, B4-05 (2004)

127. Derie, R., Depelsenaire, G., Nzihou, A., Sharrock, P.: Sludge treatment method. WO2004035490, Patent, 2004

128. Conca, J. L., Lu, N., Parker, G., Moore, B., Adams, A., Wright, J., Heller, P.: PIMS remediation of metal contaminated waters and soils. In: Wickramanayake, G.B., Gavaskar, A.R., Gibbs, J.T., Means, J.L. (eds.) Remediation of Chlorinated and Recalcitrant Compounds, vol. 7, pp. 319-326, Battelle Memorial Inst., Columbus, $\mathrm{OH}(2000)$

129. Koeppenkastrop, D., De Carlo, E.J.: Sorption of rare earth elements from seawater onto synthetic mineral phases. Chem. Geol. 95, 251-263 (1990)

130. Wright, J.V., Peurrung, L.M., Moody, T.E., Conca, J.L., Chen, X., Didzerekis, P.P., Wyse, E.: In Situ Immobilization of Heavy metals in Apatite Mineral Formulations, Technical Report to the Strategic Environmental Research and Development Program. Department of Defense, Pacific Northwest Laboratory, Richland, WA (1995) 
131. Simon, F.-G., Biermann, V., Segebade, C., Hedrich, M.: Behaviour of uranium in hydroxyapatite-bearing permeable reactive barriers: investigation using $\mathrm{U}$ as a radioindicator 237 . Sci. Total Environ. 326, 249-256 (2004)
132. Baillez, S., Nzihou, A., Bernache-Assolant, D., Champion, E., Sharrock, P.: Removal of aqueous lead ions by hydroxyapatites: equilibria and kinetic processes. J. Hazard. Mater. 139(3), 443446 (2007) 